\title{
The Influence Of Good Governance Andtransformational Leadership Styles On The Performance Of Local Governments
}

\author{
Fatmah M. Ngabito ${ }^{a}$, Asna Aneta ${ }^{\mathrm{b}}$, Arifin Tahir $^{\mathrm{c}}$, Juriko Abdussamad $^{\mathrm{d}}$ \\ a,b,c,d Gorontalo State University \\ a fatmahngabito191@gmail.com
}

Article History: Received: 10 November 2020; Revised 12 January 2021 Accepted: 27 January 2021; Published online: 5 April 2021

\begin{abstract}
This study aims to determine the effect of good governance (X1), transformational leadership style (X2), simultaneously or partially on the performance of officials in the government of North Gorontalo District. As well as the influence of Good governance (X1) on transformational leadership style (X2), the population in this study were State Civil Servants who held structural positions in seven Regional Work Units (SKPD) in the Regional Government of Gorontalo Utara Regency, amounting to 63 people, data collection principal through a list of questions that were tested on the instrument, namely the validity test and reliability test for each question item contained in the list of questions. The analytical method used is the Structural Equation Model PLS by using the Smart PLS.3.0 application.

The results showed that, Good governance (X1), has a positive and significant effect on the performance of the apparatus in the North Gorontalo District government. The effect is low with the magnitude of the effect of 0.333 or $33.3 \%$. The transformational leadership style (X2) has a significant and positive effect on the performance of the apparatus in the North Gorontalo district government. The effect is moderate with a large influence of 0.467 or $46.7 \%$. The results showed that, Good governance (X1), has a positive and significant effect on transformational leadership style (X2) in the government of North Gorontalo District. The influence is high, with the magnitude of the effect of 0.712 or $71.2 \%$. Good governance (X1) and transformational leadership style (X2) simultaneously have a positive and significant effect on the performance of the apparatus (Y) in the government of North Gorontalo District. The effect is moderate with the magnitude of the effect of 0.665 or $66.5 \%$..
\end{abstract}

Keywords: Good Governance, Transformational Leadership, Apparatus Performance

\section{Introduction}

It is very important to increase the performance of the state civil apparatus in order to create a good form of government. Mahmudi, (2015, p. 160) said that performance refers to something related to activities in doing work, in this case it includes the results achieved by the work. Meanwhile, on the one hand, the performance of the apparatus is expected to restore public confidence in the government, in this case the performance must be continuously improved.Wibowo, (2008:246) explains in detail the aspects of apatur performance appraisal determined by several indicators including quantity, quality, productivity, timeliness, cost control: Quality, which is expressed in the form of total output or percentage or comparison between actual output. and target output. a). The quantity of work is also the number of results of work in accordance with the available working time, what needs to be considered is not routine results but how quickly the work can be completed. b) Quality of work is the quality of work based on established standards. The quality of work is measured by indicators of accuracy, thoroughness, skills and job success. c). Productivity that can be measured as output per employee. the indicator. every apparatus is able to produce a job at one time, and is able to produce work on time. d). Punctuality. the indicator, measured by how much work can be completed on time, and does not delay work delay. e). Cost control, which is an indicator, is measured by how much costs are used per unit of production, and the amount of salaries or wages, either directly or indirectly. It is expected that the costs of the activities that apply in an agency can be in accordance with predetermined standards and not burdensome. As well as the apparatus can minimize mistakes in work so that costs for purchasing tools and work materials can be reduced.

Kasmir (2016: 189) states that many factors affect performance in terms of results and work behavior of officials such as abilities and skills, knowledge, job design, personality, work motivation, leadership, organizational culture, job satisfaction, work environment around, loyalty, commitment. work discipline. Meanwhile, according to Wirawan (2015: 272) states that the factors that affect employee performance include: a) Organizational External Environment, external factors of the organizational environment are factors that cannot be controlled by the organization but greatly affect employee performance such as macroeconomic factors. and micro organization, Political life, socio-cultural life, religion or spiritualism, Competitors. b) Organizational Internal 
Factors. Organizational internal factors are factors that directly affect employee performance such as organizational culture, organizational climate.

It is important to improve the performance of the apparatus by taking into account the factors that influence it. The number of factors that influence becomes a basic study so that improvements can be carried out effectively and efficiently. Various articles and research results indicate that the application of good governance and leadership styles can improve the performance of the apparatus.Achieving the performance of the apparatus requires an integrated management system or procedure as put forward Payana and Syakrani (2010: 122) which states that governance is a neutral concept, from which we can format a healthy (good) model, so that the term good appears. governance (healthy governance); or an unhealthy model (bad/despicable), a model or governance of unhealthy governance). Meanwhile, Natakusuma (2007: 32) states that good governance is an agreement regarding state regulation that is jointly created by the government, civil society and the private sector. In order to achieve good governance, it is necessary to establish dialogue between important actors in the State, so that all parties feel that they have a governance system.Good governance, where the government is currently at the limit of its capacity, that is, every time a new burden is added to the administration of government, it will mean reducing the capacity and capacity of government performance in other fields. The emergence of new thoughts that lead to changes in the pattern of government administration that involves collaboration between the government and the private sector and the community. Or better known as a paradigm shift from government (Government) to (Governance) as a form of socio-political interaction between government and society in dealing with various contemporary which are so complex, dynamic and diverse (Sedarmayanti, 2004: 24).

The three main principles that underlie the implementation of good governance are a) Transparency, the indicators of which are: open information provision, assurance of information convenience, using a queuing system for services and assigning employees based on expertise. b) Accountability whose indicators are: The existence of the right policies, improving the quality of work, being responsible, and responding to public complaints. c) Efficiency and effectiveness, the indicators are: ensuring the delivery of services, utilization of time and appropriate services. These three basic principles are universally applicable principles (Adisasmita, 2011: 38).

Research and findings that state that the implementation of good governance improves the performance of the apparatus as stated by Handi Y. L and Bambang (2016) states that the performance of a local government will be better if the principles of good government governance are applied to local governments. So indirectly good government governance basically has the aim of providing performance progress in a regional government in the province so that it can be concluded that good government governance has an influence on the performance of local governments. Furthermore, Raheni and Putri (2019) found that good governance has a positive effect on the performance of government officials. The more the implementation of good governance, the more the performance of the apparatus will increase. Likewise Saribu, (2017), that the principles of Good Government Governance, namely accountability, responsiveness, and justice have a positive effect on performance effectiveness and transparency has a negative effect.

An organization in achieving certain goals requires a series of activities known as process management. Consists of planning, organizing, mobilizing, and controlling actions through the use of human resources and other resources. Human resources play an important role in an organization, because human resources always play an active and dominant role in every organizational activity where humans reach the planners, implementers, and determinants of the realization of organizational goals. These management actions are related to each other and it is the duty of each leader to manage the resources that are in it, in this case the apparatus to carry out various jobs in order to achieve organizational goals.

One of the driving factors that can improve the performance of the apparatus is the presence of an effective leader. An effective leader is one of the important factors that affect the workings of the apparatus, wherein later job satisfaction will arise, which will eventually be seen in the work given by the apparatus. Effective leadership and improved performance of the apparatus are two factors that have been considered the basis for a successful organization. Widitmoko (2007: 17) states that improving the quality of public services is strongly influenced by the concern and commitment of leaders and government officials to carry out good governance as well as explained by Stephen Robbins 2005 that leadership is the ability to influence a group towards achieving goals.

The important role of the existence of a leader in an organization is as a guide for future direction and goals (direct setter), agent of change (agent of change), negotiator (spoke person) and coaching (Munawaroh, 2011). Hasan Ipmawan, (2015) said that the current leadership model is transformational leadership that will play an important role in the organization. Transformational leadership includes a very close relationship between leaders and with followers which is not based on agreement but rather on a relationship of trust, feeling admired, loyal, and respectful to their superiors so as to motivate their subordinates to do more than usual.

Transformational leadership is a leadership style with regard to the ways that leaders / managers influence their subordinates. Leadership style is the norm of behavior used by a leader / manager when he influences his 
subordinates. In transformational leaders, influence followers by generating strong emotions and identification with the leader, but they can also transform followers by acting as a trainer, teacher or mentor. Transformational leaders try to empower and elevate followers. Transformational followers can be found in any organization at any level. Transformational leadership also develops everyone to behave as superleaders, meaning that a transformational leader can self-lead (Luthans (2012)).

North Gorontalo Regency is one of the regencies in Gorontalo Province. As one of the youngest districts, it is necessary to study the process of developing regional apparatus in improving performance. The Regional Government of North Gorontalo District, through the regional apparatus organization, has an important role in realizing good governance. Implementing the duties of the Regional Government based on the main duties of each related Service which technically carries out its function. Therefore, government officials are demanded to be able to improve their performance and be able to provide fast service on time, productivity and a friendly attitude, and pay attention to how supervision is related to the costs incurred by the services provided.

\section{Theoritical Review}

\section{Performance Theory.}

Moeheriono (2012: 95) Performance or often called performance is a description of employee activities in determining the difference between the expected final results and actual actual results, performance can also be interpreted as a description of the level of achievement of the implementation of an activity or program and policies in realizing the goals, objectives, mission and vision of the organization as stated in the strategic or organizational plan.

Ridwan (2008: 38) says that performance depends on the regulation of ability (apablity), effort (effort) and skills (skills), also supported by the opinion of Hoy and Miskell in Ridwan (2008: 38) states that performance - $\mathrm{f}$ (Capablity X motivation), performance is determined by (a) the ability obtained and the results of education, training, experience, while (b) motivation which is the special concern and desire of an employee to do a good job. Nawawi (2008: 234) explains that performance is intended to be the result of the implementation of a job, both physical / material and non-physical / non-material in nature. In its use in the field of organizational management, the term (performance) is used to indicate or regulate the implementation and work results (achievements) achieved by a person, group or organization according to the size applicable to a task / job and within a specified time.

Wasistiono et al (2006: 45) define performance as work as the level of achievement of results or "the degree accomplishment", this means the performance level of organizational achievement. Therefore, high job effectiveness and efficiency to obtain the highest required mental attitude that has foresight. One must have an optimistic attitude, that the quality of life and life tomorrow is better than today.Wibowo (2008: 7) states that performance is the result of work or work performance, as well as how the work process takes place. Payaman J. Simanjuntak (2011.2: 83) Apparatus performance can be improved if management is able to apply effective leadership, coordinate and build work teams, choose the right technology to create a conducive working climate and atmosphere.

Gomes (2009: 142) says that performance is a record of production results on a specific job function or activity over a certain period of time. Kirom (2009: 51) states that performance is a form of separate assessment to measure the level of success achieved by a person in carrying out his work program.Sihotang (2007: 243) says that performance is actually a function of motivation and work ability. Ability without being motivated will not produce something better and useful. Wirawan (2009: 56) performance is the output produced by the functions of a job or a profession within a certain time. Prabu Mangkunegara (2014: 67) says that performance is the quality and quantity of work achieved by an employee in carrying out his duties in accordance with the responsibilities assigned to him.

Rivai (2012: 14) argues that performance is the result or level of success of a person as a whole during a certain period in carrying out a task compared to various possibilities, such as standard work results, targets or target criteria that have been determined in advance and have been mutually agreed. Samsudin (2015: 159) states that performance is the level of implementation of tasks that can be achieved by a person, unit or division that uses existing capabilities and boundaries that have been set to achieve organizational goals. Mahmudi (2015: 160) says that performance refers to something related to activities that do work, in this case it includes the results achieved by the work.Simanjuntak (2011: 175) factors that affect the performance of employees or employees, namely the ability of employees or employees for the job, the level of effort spent, and the organizational support they receive. With regard to any management function, human resource management activities should be developed, evaluated and modified where necessary so that they can contribute to the competitive performance of 
organizations and individuals in the workplace. Employee factors for doing the job, level of effort put into it, and organizational support.

Employee performance is basically the work of employees during a certain period compared to various possibilities, for example standards, targets / targets or criteria that have been determined in advance and have been mutually agreed upon. Pasolong (2008: 197) is work performance, which is determined by environmental factors and management behavior. Mahmudi (2010: 6) states that performance is the result of work itself (outcomes of work), because work results provide a strong link to organizational strategic goals, customer satisfaction, and economic contributions. Then Campbell in Mahmudi (2010: 21) states that the functional relationship between performance and performance attributes is influenced by three factors, namely the factors of knowledge (knowledge), skills (skills) and motivation.

Performance appraisal is an assessment made to the management of an organization both to individual employees and to leaders or managers who have been doing work. Fahmi, (2010: 65) performance appraisal is a process of evaluating how well employees do their work when compared to a standard and then communicating that information. The results of the assessment carried out will be used as input for assessing further performance so that corrections and improvements can be made or calle d continuous improvement.

\section{Good Governance}

Dwi Payana (2010: 45) The term Good Governance is something that is difficult to define because it contains ethical meanings. In the sense that something that is considered good in one society, but for other communities does not necessarily get the same assessment. Various definitions of good governance are as follows: "good governance" is often defined as "good governance". There are also those who interpret it as good governance and there are also those who interpret it as a good government system.Dwi payana and Eko Syakrani (2010: 122) states that governance is a neutral concept, from which we can formulate a healthy (good) model, so that the term good governance appears; or an unhealthy model (bad / despicable), a model or governance of unhealthy governance). Rochman (2007: 197) states that governance is a mechanism for managing economic and social resources that involves the influence of the state sector and the non-government sector in a collective effort.Adisasmita (2011: 22) says that governance has three supports, namely economic, social and administrative. Economic governance includes a decision making process that facilitates economic activity in the country and the interactions between economic administrators. Economic governance has implications for equity, powerty, and quality of life (realizing justice, alleviating poverty, and creating a better quality of life). Sedarmayanti (2004: 25), according to the characteristics of good governance, has three main pillars, namely: transparency, law enforcement and accountability, the process of democratizing government politics, nowadays it not only demands professionalism and the ability of the apparatus in public services but fundamentally demands the realization of a good government. good, clean, and free of corruption, collusion, and nespotism or KKN (Good Governance and Clean Government).

Natakusuma (2007: 32) says that good governance or good governance is an agreement regarding State arrangements that is jointly created by the government, civil society and the private sector. In order to realize good governance, it is necessary to establish dialogue between important actors in the State, so that all parties feel that they have a governing system of governance. Without the agreement that is born from this dialogue, prosperity will not be achieved because the political and economic aspirations of the people are stagnated.

Effendi and Sujardi (2009: 19) Government and governance are often considered to have the same meaning, namely how to exercise authority in an organization, institution or state. Government or government is also the name given to entities that exercise governmental power in a country. Kaloh (2009: 172) theoretically good governance implies that power management is based on applicable legal rules, transparent policy making, and accountability to society. Power is also based on institutional aspects and not on the will of a particular person or group. Power must also comply with the principle that the State has equal rights and obligations before the law.

Adisasmita (2011: 38) three main principles that underlie the implementation of good governance are a) Transparency, the indicators are: open provision of information, guarantee of information convenience, using a queuing system for services and assigning employees based on expertise. b) Accountability whose indicators are: The existence of the right policies, improving the quality of work, being responsible, and responding to public complaints. c) Efficiency and effectiveness, the indicators are: ensuring the delivery of services, utilization of time and appropriate services. These three basic principles are principles that apply universally.Natakusuma (2007: 32) says that good governance or good governance is an agreement regarding State arrangements that is jointly created by the government, civil society and the private sector. In order to realize good governance, it is necessary to establish dialogue between important actors in the State, so that all parties feel that they have a governing system of governance. Without the agreement that is born from this dialogue, prosperity will not be achieved because the political and economic aspirations of the people are stagnated. Effendi and Surjadi (2009: 19) government and governance are often considered to have the same meaning, namely how to exercise authority in an organization, 
institution or state. Government or government is also the name given to the identity that administers the power of governance in a country. Kaloh (2009: 172) theoretically good governance implies that power management is based on applicable legal rules, transparent policy making, and accountability to the community. Power is also based on institutional aspects and not on a particular person or group.

\section{Leadership}

Pasalong (2010: 2) says that a leader is a vioner as a person who is willing to step into an unknown situation. Leaders who have a clear vision can be a guide in carrying out their main duties and functions as a leader. Fahmi (2010) a leader in a broad sense is "someone who leads, by initiating social behavior by regulating, demonstrating organizing or controlling the efforts (efforts) of others or through prestige, power or position". Pasalong (2010:2) states that a leader is a person who has certain superiority, so that he has the authority and power to move others to make joint efforts to achieve certain goals. Meanwhile, Syafi'ie (2009: 1) says that a leader is a person who influences other parties through a process of communication authority so that the other person acts something in order to achieve certain goals.

Wirjana (2006: 4) says that a leader is "a person who occupies a group position influencing people in the group according to the expectations of that role and position, and coordinates and directs the group to defend itself and achieve its goals". Rivai (2010: 65) states that a leader is a member of a group who is given a certain position and is expected to act according to his position, so the leader is also someone in an association who is expected to use his influence to realize and achieve group goals. Sudriamunawar (2006: 1) a leader is someone who has certain abilities that can influence his followers to work together towards achieving predetermined goals.

Syamsul Arifin (2012: 4) Leadership is the ability to persuade people to achieve firm and passionate goals. Siagian (2007: 86) Leadership is a process of directing and influencing activities related to the tasks of the group. Behavioral leadership is leadership based on observations of what effective leaders are doing. Leadership here provides leeway for individuals to realize their own potential motivations to satisfy needs while at the same time contributing to the achievement of organizational goals.Kartini Kartono (2013: 32) leadership is the process of influencing the interpretation of the events of the followers, the choice of target groups or organizations, organizing these activities to achieve the goal of maintaining cooperation and teamwork, as well as gaining support and cooperation from people who are outside groups and organizations. Safaria in Syamsul Arifin (2012: 6) says that leadership is one of the easiest phenomena to observe, however, it is one of the most difficult to understand.

\section{Research Methods}

This research will be carried out at the Regional Government of North Gorontalo Regency, in this case the Regional Apparatus Organization Unit (SKPD), including: Fisheries and Marine Service, Population and Civil Registration Service, Civil Service Agency, Environmental Agency, Library Office, Regional Civil Service Agency, and the Family Planning Office. And Women's Empowerment.This research uses quantitative research, according to Sugiyono (2017: 8) quantitative research can be interpreted as a research method based on the philosophy of positivism, used to research on certain populations or samples, data collection using research instruments, data analysis is quantitative statistics, with the aim of testing the hypotheses that have been determined. The quantitative research used uses an explanatory survey approach. The explanatory survey method is a research method that is carried out on large and small populations, but the data studied is data from a sample taken from that population so that the descriptions and relationships between variables are found.

The data collection techniques used in the study were adjusted to the required data sources. The data sources used are primary data obtained through questionnaire and observation techniques and secondary data obtained through documentation and literature studies on important notes that support research results, namely those related to Good Governance and Transparency Leadership Style of Apparatus Performance. In the Regional Government of North Gorontalo District.(Mulyadi, 2016: 122).

In testing a hypothesis, various methods of analysis can be used, one of which is the Structural Equation Modeling (SEM) analysis with the PLS method, steps are carried out based on Ghozali and Latan (2015: 47-54). 


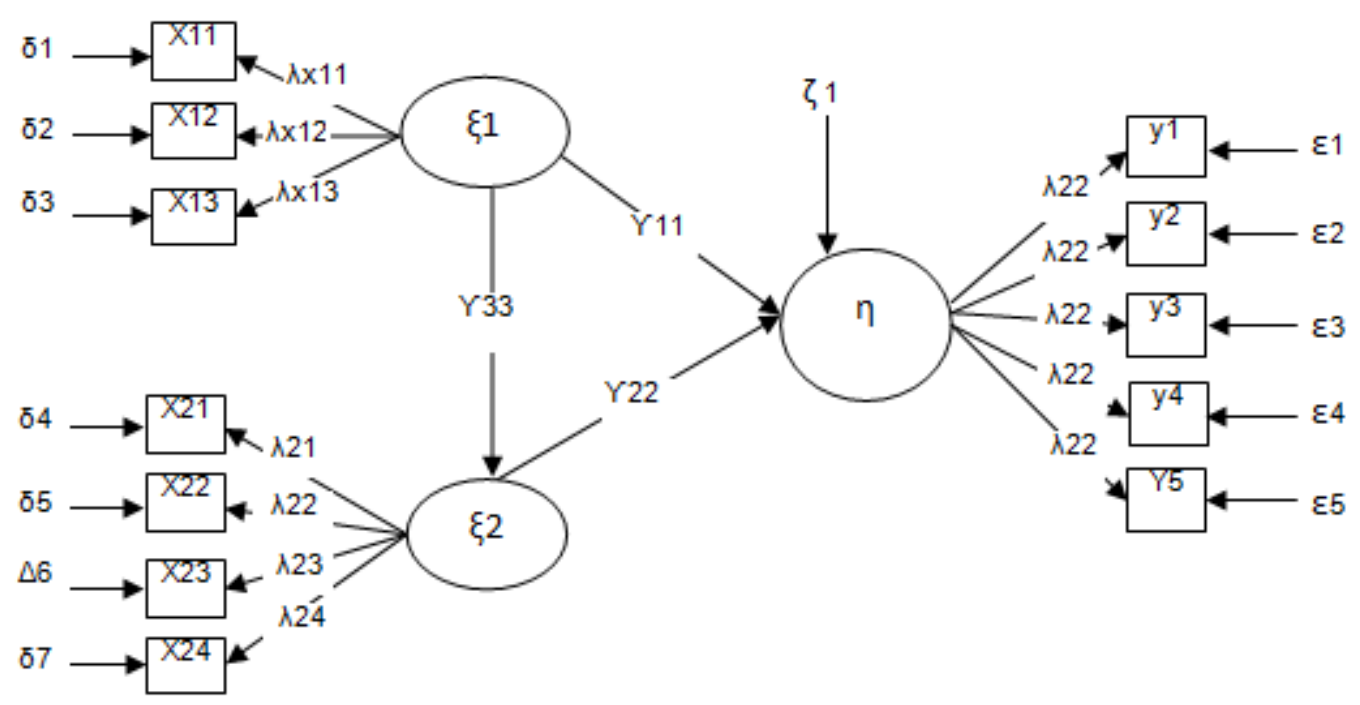

Figure 3.2. Model Structural Equation Model

\section{Research Results And Discussion}

\section{Research result}

The following is a picture of the calculation results of the SEM PLS model, which can explain the loading factor value of the indicators for each variable.

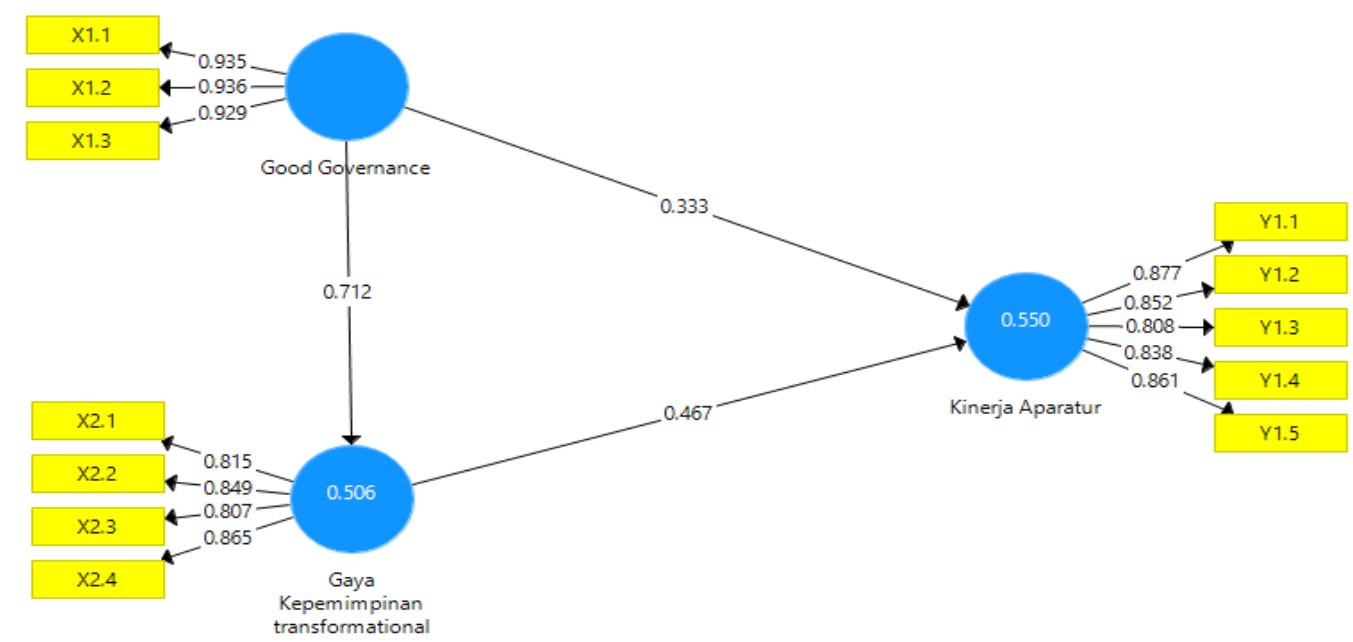

Figure 4.5 Structural Equation Model PLS 


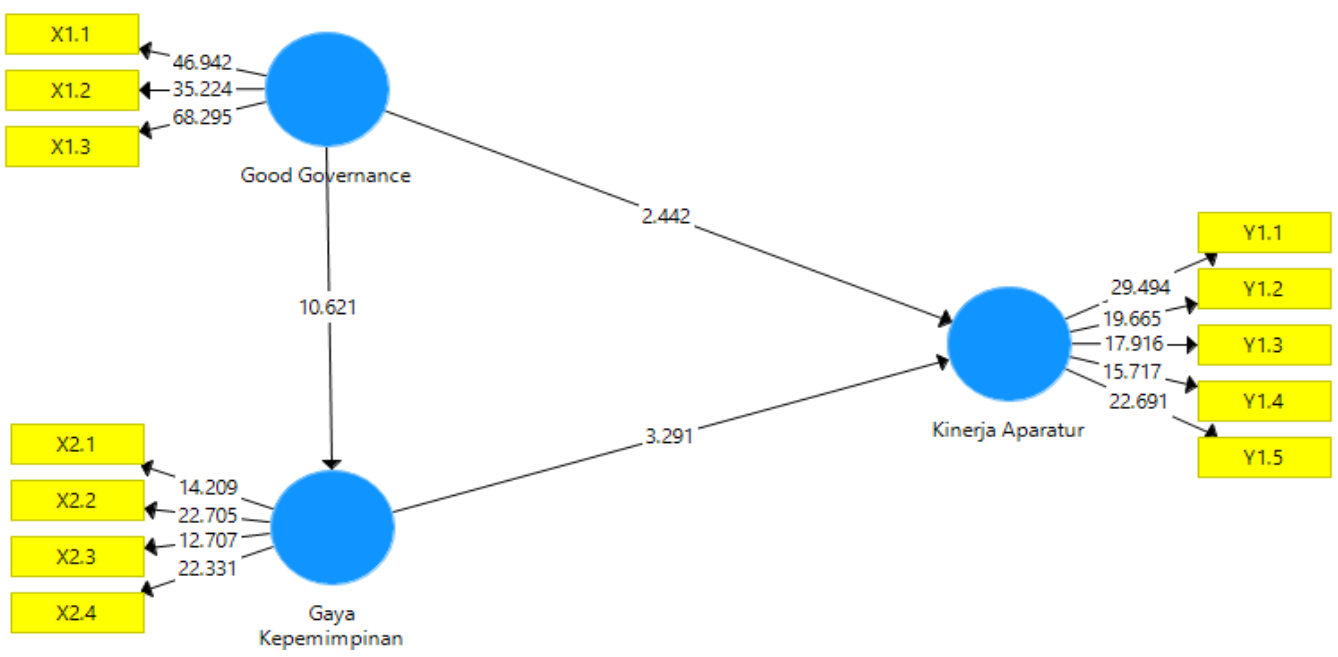

Figure 4.6 Inner Model

Based on the results of data processing, it can be explained and tested the outer model, including:

\section{Convergent Validity}

Convergent validity (convergent validity) is performed to determine the validity of each relationship between the indicator and its latent construct or variable. The convergent validity of the measurement model with a reflective indicator is assessed based on the correlation between item scores or component scores with latent variable scores or construct scores estimated by the Smart PLS program.

\section{a. Variable X1 Good Governance}

The results of the calculation of the Good governance variable can explain the loading factor value of each indicator that makes up these variables as below:

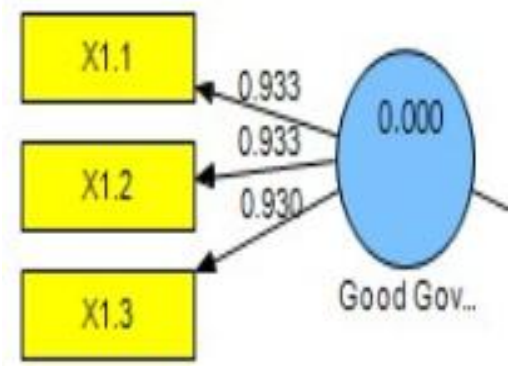

Figure 4.7 Loading Factor variable X1

Based on the data in Figure 4.7, it can be explained that all indicators in the good governance variable have a loading factor value greater than>0.6. Based on the table above shows that the variable good governance is measured by 3 (three) dimensions, including transparency with a factor loading value of $0.933(93.3 \%)$, the accountability dimension with a factor loading value of 0.933 (93.3\%), efficiency and effectiveness with a loading factor value of $0.930(93.0 \%)$. These results indicate that the good governance variable with an indicator whose loading factor value is above 0.60 has a high level of validity or meets convergent validity.

\section{b. Variable X2 Transformational Leadership Style}

The results of the calculation of the Transformational Leadership Style variable can explain the loading factor value of each indicator that forms these variables as below: 


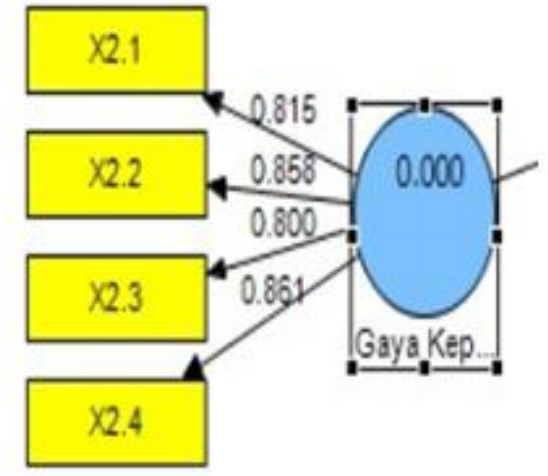

Figure 4.8 Loading Factor variable X2

Based on the data in Figure 4.8, it can be explained that all indicators in the Transformational Leadership Style variable have a loading factor value greater than>0.6. Transformational leadership variables are measured by 4 (four) dimensions, including: ideal influence with a loading factor value of 0.815 (81.5\%), inspirational motivation of $0.858(85.8 \%)$, intellectual stimulus with a loading factor value of $0.800(80.0 \%)$, and individual attention with a loading factor value of $0.861(86.1 \%)$. These results indicate that the transformational leadership variable with an indicator whose loading factor value is above 0.60 has a high level of validity or meets convergent validity.

\section{c. Variable Y Performance}

The results of the calculation of the variable performance of the apparatus can explain the loading factor value of each indicator that makes up these variables as below:

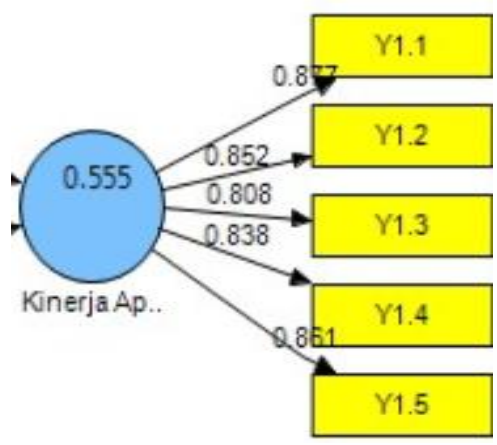

Figure 4.9 Loading Factor variable Y

Based on the data in Figure 4.9, it can be explained that all indicators on the apparatus performance variable have a loading factor value greater than> 0.6. Apparatus performance variables are measured by 5 (five) dimensions, including the quantity dimension with a loading factor value of $0.877(87.7 \%)$, the quality dimension with a loading factor value of $0.852(85.2 \%)$, the productivity dimension with a loading factor value of 0.808 . $(80.8 \%)$, the dimension of timeliness with a loading factor value of $0.838(83.8 \%)$, and the dimension of cost control with a loading factor value of $0.861(86.1 \%)$. These results indicate that the apparatus performance variable with an indicator whose loading factor value is above 0.60 has a high level of validity or meets convergent validity.

\section{Discussion Of Research Results}

Referring to the research data, the good governance variable empirically has a positive and significant effect on the performance of the apparatus. These findings indicate that the more good governance is implemented, the performance of the apparatus will increase. Good Governance is a good government system. Governance as a process of exercising state power in implementing public good and services. Meanwhile, the meaning of "good" in "good governance" contains two definitions, first, values that uphold the wishes / will of the people, and values that can increase people's ability to achieve (national) goals of independence, development, sustainability and social justice. ; second, the functional aspects of government that are effective and efficient in carrying out their duties to achieve these goals. Therefore "good governance" is defined as the implementation of a government that is solid and responsible, as well as effective and efficient by keeping constructive interactions between the domains of the State, the private sector and the public ". (Dwi Payana, 2010: 45). 
Referring to the research data, that the Transformational leadership style variable empirically has a positive effect on the performance of the apparatus. These findings indicate that the more transformational leadership is applied, it will be followed by an increase in the performance of the apparatus. The magnitude of the influence of the transformational leadership style on the performance of the apparatus in North Gorontalo Regency is in the moderate category, this is due to the fact that there is still a transformational leadership style that has not been optimally applied by the leadership in the government of North Gorontalo Regency. The findings of the study reveal that the application of a leadership style that is not optimal is the indicator of ideal influence where it is found that based on the results of the questionnaire it is known that the leader still lacks confidence in subordinates with the lowest value of all statements from the respondents. Trust is a very important thing in applying transformational leadership style. This is in accordance with what Yulianti, Wuryanti, (2015) said that trust will encourage and simplify complexity, help develop capacity for action, increase collaboration and improve organizational learning abilities. Furthermore, it is said that trust is a person's willingness to rely on other people in whom we have confidence. Without trust as the core of every human relationship, a boss will not be able to complete the tasks assigned to him properly. To gain the trust of his subordinates and vice versa, a superior / subordinate must be competent with his job, reliable by his superior / subordinate, open and caring about his superior / subordinate.

Referring to the research data, the good governance variable empirically has a positive and significant effect on transformational leadership style. These findings indicate that the more good governance is implemented, the more transformational leadership styles are implemented. This can be explained that the implementation of good governance in the North Gorontalo district government has been implemented well. This can be seen from the implementation of the indicators of transparency, efficiency and accountability which are good even though there are still some that are not yet optimal. The implementation of transparency is carried out well by implementing a good queuing system, providing information openly to stakeholders even though it is not optimal, the placement of employees who understand their work is still constrained by the availability of resources with appropriate competencies. as well as adequate guarantee of information ease.This is in line with Adisasmita (2011: 38) which states that transparency is the openness of the government in providing information related to public resource management activities to parties who need information. The government is obliged to provide information and other information that will be used for economic, social and political decision making by interested parties through accounting information, one of which is in the form of financial reports.

Referring to the research data, the variables of good governance and transformational leadership style empirically have a positive and significant effect on the performance of the apparatus. These findings indicate that the more implemented jointly good governance and transformational leadership style, it will be followed by an increase in the performance of the apparatus. Good governance is a solid and responsible implementation of development management that is in line with the principles of democracy and efficient markets, avoiding misallocation of investment funds and preventing corruption both politically and administratively implementing budget discipline as well as creating a legal and political framework for the growth of business activities. Basically, good governance is a concept that refers to the process of achieving decisions and their implementation which can be accounted for collectively. As a consensus reached by the government, citizens and the private sector for the administration of government in a country.

Good Governance in Indonesia itself has really been initiated and implemented since the outbreak of the reform era, which in that era there has been an overhaul of the government system which demands a clean democratic process so that Good Governance is one of the tools of reform that is absolutely applied in the new government, Judging from the development of the Reformation that has been running for 15 years, the implementation of Good Governance in Indonesia cannot be said to be fully successful in accordance with the ideals of the previous Reformation. There are still many frauds and leaks in budget management and accounting, which are the two main products of Good Governance.

\section{Conlusion}

Good governance has a positive and significant effect on the performance of the apparatus, which means that the more good governance is implemented, the better the performance of the apparatus. The results of this study indicate that good governance, which is measured by using 3 reflexive dimensions, including transparency, accountability and efficiency and effectiveness, has made a positive and significant contribution to improving the performance of the apparatus in carrying out their functions and responsibilities as service providers to society so that it has the potential to increase performance both individually and in an organization. The transformational leadership style has a positive effect on the performance of the apparatus, which means that if the transformational leadership style is applied in the organization, it will also be followed by an increase in the performance of the apparatus. These results indicate that there is a direct influence of transformational leadership style on apparatus performance. The implementation of good governance is able to influence the leadership to apply a 
transformational leadership style, because transformational leadership is based on the implementation of accountability, responsibility and efficient and effective governance, the charisma of the leadership to always provide motivation to employees in realizing good public services..

\section{References}

Ardana, Komang, et al. 2008. Organizational Behavior. Yogyakarta: Graha Science.

Adi Sasmita 2011. Governance Has Three Supports Economic, Social Administrative. Graha Ilmu. Yoyakarta.

A. Dale Timpe 2002. Human Resource Management Leadership Series.

Agus Setiawan 2013. Transformation Leadership Illustration in the Field of Educational Organization. PT. Raja Grapindo Persada.

Bahar Agus Setiawan and Abd. Muhith. 2013. Transformational Leadership. Jakarta: PT Raja Grafindo Persada.

Bass, Bernand M. \& Ronald E. Riggio, 2006.Tranformation Leadership. The United States Of America: Lawrence Erlbaum Associates, Inc Leadership.

Get up, Wilson. 2012. "Human Resource Management". Jakarta: Erlangga

Burns, J. M. (1978). Leadership. New York, NY: Harper \& Row.

Bennis, 2010. Leadership. Sinar Grafika, Jakarta.

Bolman, Leeg. And Deal, Terece E. 2001. Leading With Soul: An Uncommon Jounaly Of Spiit. San Francisco: Jossey- Bass.

Dwi Payana, 2010. The term Good Governance. PT. Raja Granfindo Pustaka Jakarta.

Dessler, Gary, 2010. Human Resource Management, Jakarta: PT. Index.

Eddi Wibowo 2011. Good Governance. Cipta Mandiri Yogyakarta.

Effendi, Muh. Arief. 2009. The Power Of Corporate Governance: Theory and. Implementation. Jakarta: Four Salemba

Eko, Widodo Suparno. 2015. Resource Development Management. Human. Yogyakarta: Student Library.

Fahmi 2010. Performance Measurement. PT. Refika Aditama Bandung.

Farazmand, Ali, 2004, Sound Governance: Policy And Administrative Innovations, Praeger Publishers

Fieder, Fred E. 1967. A Theori Of Leadership Effectiveness. Houghton Mifflin, Co.

Cashmere. (2016). Human Resource Management (Theory and Practice). Jakarta: PT Raja Grafindo Persada.

Kartini Kartono 2013. Formal Leader, Informal Leader. Sinar Grafindo Persada Jakarta.

Kartini Kartono 2014. Leader and Leadership of PT. Raja Grafindo Persada Jakarta.

Kiron 2009, Measuring Service Performance and Customer Satisfaction, Pustaka Reka Cipta Bandung.

Kaloh. The Leader Between Success And Failure. Hasta Library.

Kartono 2008. Formal Leaders, Informal Leaders. Sinar Grafida Jakarta.

Kondalkar, V.G. 2007. Organization Behavior. New Delhi: New Age International (P) Limited, Publishers.

Kipnis, David. 1976. The Power Holdesr. Chicago: University Of Chicago Press.

Kreitner, Robert; and Kinicki, Angelo, 2005, "Organizational Behavior", Book 1, Edition. Fifth, Salemba Empat, Jakarta.

Khalid Jamal, 2007, Teach Me Love (Intelligent Reflection Towards True Love) Translator; Budiman Mustofa, Surakarta: Ziyaad Books,

Lee, Percy-Smith. 2008. Governance. Pt. Raja Grafindo Pustaka, Jakarta.

LAN, RI 2009. Accountability and Good Governance. Cipta Mandiri Yokyakarta.

Luthans, Fred and Doh, Jonathan P. (2012). International Management 8th Ed. New York: McGraw-Hill.

Mahmudi 2015. Public Sector Performance Management, Yogyakarta UPP. YKPN.

Mahmudi, 2010. Public Sector Performance Management. Yogyakarta UPPN. YKPN.

Malayu S.P. Hasibuan 2001. Authority and Leadership. PT. Earth Literacy Jakarta.

Mangkunegara Ap. 2014. Human Resource Management. Bandung Renata Rosda Karya.

Mangkunegara. 2011. Company Resource Management. PT. Youth. Rosdakarya. Bandung

M Tauf'q Amir. (2012). Passion, Engagement and Thriving at Work Maximizing Individual Potential

Moeheriyono 2012. Public Sector Performance. Jokjakarta. Main Library.

Natakusuma, 2007. Implementation of Good Governance. Paddeglan Regency Government. Banten.

Nawawi, Hadari. 2008. Human Resource Management. For competitive businesses. Gajah Mada University Press, Yokyakarta.

Nevid, Jeffrey S., Rathus, Spencer A., \& Greene Beverly. (2005). Introduction to Abnormal Psychology. Bandung: Erlangga.

Payaman. J. Simanjuntak. 2011. Management and Performance Evaluation. Publishing Institute, Faculty of Economics, UI. Jakarta.

Pasolong, 2008. Performance management theory and applications. Alfabeta Bandung.

Prawirosentono, Suyadi. (2012). Human Resource Management, Employee Performance Policy, Tips for Building a Competitive Organization in the World Free Trade Era. Yogyakarta: BPFE.

Rivai, 2012. Human Resource Management. Jokjakarta Elexmedia. 
Rosidah 2003. Human Resource Management. Graha Ilmu. Yokyakarta.

Rochman 2007. Implementation of Regional Autonomy in Prospective Good Governance. Jokjakarta.

Robert 1992. Kinds of Leadership Style. Andi Jokjakarta.

Rogers, Mahmudi, 2010. Public Sector Performance Management. Publishing Unit for YKPN Management Academy, Yokyakarta.

Ridwan 2008. Methods and techniques for preparing a thesis proposal. Alfabeta Bandung.

Rue, Bryas, Waistiono et al, 2007. Reorganizing District Government Institutions. Citra Pindo Bandung.

Samsudin, 2015. Human Resource Management. Bandung Pustaka Setia.

Sudriamunawar. Haryono 2006. Leadership, Participation and Productivity. Prints I. Bandung: Mandar Maju.

Sedarmayanti, 2009. Good Governance. Mondar Forward Bandung.

Simanjuntak 2011. Performance Evaluation Management, LP FEUI, Jakarta.

Sihotang, 2007. Human Resource Management. PT. Praditiya Paramita Jakarta.

Siagian 2002. Theory of Motivation and Its Application. Rineka Cipta Jakarta.

Siagian2007. Motivation Theory and Its Application. Rineka Cipta Jakarta.

Syafi'ie Inu Kencana, 2003. Indonesian Government Leadership. PT. Refika Aditama Bandung.

Syamsul Arifin 2012. Leadership Science and the Arts of Leadership. Mitra Wacana Media Jokjakarta

Sugiono 2008. Quantitative Research Methods, Qualitative, And R \& D. Alfabeta Bandung.

Sudria Munawar 2006. Leadership in Management of PT. Raja Grafindo Persada Jakarta.

Sternberg, J Robert \& Sternber Karin. 2009. Cognitive Psychology 6th Edition. United States America: Wadsworth Cengage Learning

Terry, G. 2001. Prinshiples Of Management, Richard D. Irwin Inc. Homewood, Ilinois.

Tompubulon 2007. Leadership Style. PT Raja Granfindo Persada Jakarta.

Wasistiono Sadu \& Irwan Tahir, 2006: Village Development Prospects, Bandung: CV. Focus media

Wibowo, 2008. Performance Management. PT. Raja Grafindo Persada Jakarta.

Widiatmoko 2007. Public Service Through a Systems Approach in the Application of Public Administration Ecology, Lan Ri. Jakarta.

Winardi 1983. Leadership Style. Mitra Kencana Jakarta.

Wirawan 2009. Evaluation of Human Resources Performance. Jakarta Rajawali Press.

Wirawan, 2015. Performance Evaluation of Human Resources (Theory, Application, and Research). Jakarta: Four Salemba

Wirjana, Bernadine 2006. Leadership Basics and Development. Jokjakarta.

Yuki 2010. Leadership in Organizations. Fifth Edition PT. Gramedia Index.

Yulk, Gray 2015. Leadership in Organizations. Fifth Edition PT. Gramedia Index 